\title{
ESSAY
}

\section{WILLIAM O. DOUGLAS AS A COMMON LAW JUDGE}

\author{
MELVIN I. UROFSKY*
}

Few Justices of the United States Suprene Court created as nuch controversy during their lifetimes as did William O. Douglas. ${ }^{1}$ During his record thirty-six years on the bench, he forcefully spoke on issues as wide-ranging as American foreign affairs and the environment; traveled around the world, visiting "strange lands and strange people"; 2 wrote dozens of books and articles on a variety of topics aimed at the general public; ${ }^{3}$ and divorced and reniarried three times. ${ }^{4}$ In addition, he chan1pioned the liberal position on nearly every issue before the Court. Justice Douglas's political and judicial liberalisn1, as well as his idiosyncratic lifestyle, infuriated conservatives. In 1970, these conservatives, led by then-Congressnian Gerald R. Ford, attempted to impeach him. ${ }^{5}$

Of course, Douglas has not been without his chanipions. Upon his retirement front the Court, his former pupil, lifelong friend, and occasional colleagne, Abe Fortas, declared that "[t]hroughout his life, Douglas has fiercely occupied high ground-the highest that hife on this earth offers. He is, of course, an idealist; but, for him, ideals are not abstractions; they are objectives demandinig present fulfillment." One of his favorite law clerks, Vern Countryman, wrote extensively on Douglas and the enduring impact his opimions and dissents have had on American

* Professor of History, Virginia Conımonwealth University. B.A., Columbia University, 1961; Ph.D., Columbia University, 1968; J.D., University of Virginia, 1983.

1. Justice William O. Douglas served on the Supreme Court fron 1939-1975.

2. William O. Douglas, Strange Lands and Friendly People 317 (1951); see also id. at 291-327 (recounting his trip abroad through the Middle East and into India, and criticizing American foreign policy in that region).

3. See, e.g., William O. Douglas, Of Men and Mountains (1950); William O. DougLas, Go East, Young MaN (1974) [hereinafter Go East]; William O. Douglas, The Court YEARS (1980) [hereinafter CouRT YEARs] (antobiographies).

4. See James F. Simon, Independent Journey: The Life of William O. Douglas 404 06 (1980).

5. See Special Subcomm. of House Judiciary Comm., 91st Cong., 2D Sess., Final RePORT ON H.R. RES. 920 (Comm. Print 1970). The subcommittee of the House Judiciary Committee assigned to look into the charges found them all lacking in substance. See id. at 349.

6. Abe Fortas, William O. Douglas: An Appreciation, 51 IND. L.J. 3,3 (1975). 
constitutional development. ${ }^{7}$ Others have written more specifically on his contributions to the First Amendment freedoms of speech $^{8}$ and religion, ${ }^{9}$ civil rights, ${ }^{10}$ and especially privacy. ${ }^{11}$

A decade after his death in January 1980, William O. Douglas remains a figure surrounded by controversies concerned with his jurisprudence or lack of it. This Article will first examine soine of that criticisin, and then suggest that one way to evaluate his contributions to American constitutional development is to view him as a common law judge. A definition of common law judging will be offered, and then some of Douglas's most important (and most controversial) decisions will be exammed agamst that defimition. The Article will thus demonstrate that despite the criticism, Justice Douglas not only utilized a coherent approach in his judging, but significantly contributed to the growth of American constitutional law in the mid-twentieth century.

\section{Douglas and His Critics}

Criticism of Douglas can be divided into two categories. First, as a political judge he decided cases according to the results his political views dictated. Thus, as a liberal, he believed in a right of privacy, 12 stringent limits on government intrusion, ${ }^{13}$ and in the rights of illegitimate cliildren. ${ }^{14}$ The second criticism, derived from the first, is that he did not develop a coherent, acceptable legal analysis in his decisions so that scholars and other judges could draw a useful pattern from his opinions. Rather, Douglas went right from question to result with only the

7. See, e.g., Vern Countryman, The Contribution of the Douglas Dissent, 10 GA. L. REv. 331 (1976); Vern Countryman, Even-Handed Justice, 11 HARv. C.R.-C.L. L. Rev. 233 (1976); Vern Countryman, Justice Douglas and Freedom of Expression, 1978 U. ILL. L.F. 301. Countryman also edited a representative sampling of Douglas's Court work. VERN COUNTRYMAN, THE DougLas Opinions (1977).

8. See Maury Maverick, Jr., Douglas and the First Amendment-Visiting Old Battlegrounds, 28 BAYLOR L. Rev. 235 (1976); Lucas A. Powe, Jr., Evolution to Absolutism: Justice Douglas and the First Amendment, 74 Colum. L. Rev. 371 (1974); Lucas A. Powe, Jr., Justice Douglas After Fifty Years: The First Amendment, McCarthyism and Rights, 6 Const. CoMmENTARY 267 (1989) [hereinafter Powe, Douglas After Fifty Years].

9. See Nadine Strossen, The Religion Clause Writings of Justice William O. Douglas, in "HE Shall Not Pass This Way Again": The Legacy of Justice William O. Douglas 91 (Stephen L. Wasby ed., 1990) [hereinafter LEGACY OF JUSTICE DougLAS].

10. See Drew S. Days III, Justice William O. Douglas and Civil Rights, in LEGACY OF JUSTICE Douglas, supra note 9, at 109.

11. See Dorothy J. Glancy, Getting Government Off the Backs of People: The Right of Privacy and Freedom of Expression in the Opinions of Justice William O. Douglas, 21 SANTA ClaRA L. REv. 1047 (1981); Sheldon S. Adler, Note, Toward a Constitutional Theory of Individuality: The Privacy Opinions of Justice Douglas, 87 Y ALE L.J. 1579 (1978).

12. See infra text accompanying notes 94-100.

13. See infra text accompanying notes 122-28.

14. See infra text accompanying notes 110-12. 
barest justification, or with a rationale that stretched a tenuous or unacceptable mode of reasoning.

Criticism of Douglas and his activist colleagues on the Stone Court-notably Hugo Black and Frank Murphy-came early in Douglas's career. Within the Court, Felix Frankfurter, the self-proclaimed inheritor of the niantle of judicial self-restraint from Holmes and Brandeis, attacked the "Axis," as he termed them, for their failure to follow his lead and to adhere to strict standards of judicial decisionmaking. ${ }^{15}$ The willingness of Douglas and the other activists to overturn prior decisions $^{16}$ and to expand the reach of the Bill of Rights ${ }^{17}$ also elicited coinplaints from some lower court judges, such as Learned Hand, who shared much of Frankfurter's anger toward the "Axis."18

Thonias Reed Powell, a professor at the Harvard Law School and a friend of both Douglas and Frankfurter, lamented (only partially in jest) that he was afraid to meet his classes on Monday until after the Court handed down its opinions. In this way, he would know what Douglas and the other activists had done, and whether the law that had been that morning still held true in the afternoon. ${ }^{19}$

Yosal Rogat, in a 1964 review of two of Douglas's books, exemplified the two major criticisms of Douglas. He charged that Douglas, despite his avowed support of judicial restraint, ${ }^{20}$ "rejects the austerity and detachment traditionally imposed upon a judge. Indeed, he has come to think of himself as no mere judge, but [as] a moralist, a political vision-

15. See Melvin I. Urofsky, Conflict Among the Brethren: Felix Frankfurter, William O. Douglas and the Clash of Personalities and Philosophies on the United States Supreme Court, 1988 DUKE L.J. 71, 84-113; see also James F. Simon, The ANTAgonists: Hugo Black, Felix FrankFURTER AND CIVIL LIBERTIES IN MODERN AMERICA 105-29 (1989).

16. See, e.g., West Virginia State Bd. of Educ. v. Barnette, 319 U.S. 624 (1943) (overruling Minersville School Dist. v. Gobitis, 310 U.S. 586 (1940)).

17. See, e.g., Bridges v. California, 314 U.S. 252 (1941) (expanding the reach of the First Amendment).

18. Hand wrote:

[T]hose reforming colleagues of yours. As soon as they convince the people that they can do what they want, the people will demand of them that they do what the people want. I wonder whether in times of bland reaction-[and] they are coming-Hillbilly Hugo

[Black], Good Old Bill [Douglas] and Jesus lover of my Soul [Murphy] will like that.

Letter from Learned Hand to Felix Frankfurter (Feb. 6, 1944) (available in Felix Frankfurter Papers, Manuscript Division, Library of Congress, Washington, D.C.).

19. Letter from Thomas Reed Powell to William O. Douglas (Mar. 28, 1944) (available in Thomas Reed Powell Papers, Harvard Law School Library, Cambridge, Mass.).

20. "It is the very essence of a government of laws that the predilections of judges not carry the day, and that the law as written by the lawmakers be applied equally to all. This I had assumed to be elementary." William O. Douglas, On Misconception of the Judicial Function and the Responsibility of the Bar, 59 COLUM. L. REv. 227, 227 (1959). 
ary, a universal philosopher."21 These traits, Rogat clainied, informed not only Douglas's books, but his court opinions as well:

[A] case does not present a tangle of competing principles, but a single transcendent principle-for instance, free speech or religious freedom-which need only be identified for the solution to be plain. In this way, he avoids the task, so basic to legal analysis, of reconciling competing principles. Instead, he substitutes simple labels and lines: "the abuse of speech can be punished but the right itself cannot be." Unfortunately, few cases are so simple. ${ }^{22}$

Rogat went on to castigate Douglas for the carelessness of his opinions and his indifference to legal analysis. Rogat attributed this slipshod jurisprudence to Douglas's "exclusively political conception of the judicial role." 23

Shortly after Douglas retired from the Court, Bernard Wolfnian, a professor of tax law at the University of Pennsylvania Law School, weighed in with an analysis of Douglas's votes in the 278 federal tax cases decided during his tenure on the bench. ${ }^{24}$ Wolfman found that in his early years on the Court, Douglas wrote many tax opinions sustaining the Government's positions. Yet he began to dissent, usually in favor of the taxpayer:

And he often dissented alone, without opimion, or with only a few words. In the last decade and a half particularly, Douglas' positions in tax cases have been inarked by a strong disposition in favor of taxpayers' positions, a lack of syinpathy with the administration of the Internal Revenue Service ... and an increasing failure to explain his votes in well-reasoned opinions. ${ }^{25}$

The most sustained attack on Douglas's judicial record has come from G. Edward White. ${ }^{26}$ White castigates Douglas for rejecting "both of the principal twentieth-century devices designed to constrain subjective judicial lawniaking: fidelity to constitutional text or doctrine, and mstitutional deference."27 White subjects Douglas's autobiographical writings to an extensive psychological analysis because he believes that

21. Yosal Rogat, Mr. Justice Pangloss, N.Y. REv. of Bks., Oct. 22, 1964, at 5, 5 (reviewing William O. Douglas, The ANatomy of Liberty (1963) and William O. Douglas, Freedom OF THE MIND (1964)).

22. Id. at 6.

23. $I d$.

24. Bernard Wolfman et al., Dissent Without Opinion: The Behavior of Justice William O. Douglas in Federal TaX Cases (1975). An earlier version appeared as Bernard Wolfman et al., The Behavior of Justice Douglas in Federal Tax Cases, 122 U. PA. L. REv. 235 (1973).

25. Wolfman, supra note 24 , at 4.

26. See G. Edward White, The Anti-Judge: William O. Douglas and the Ambiguities of Individuality, 74 VA. L. REV. 17 (1988).

27. Id. at 18. 
the "compelling personal themes of Douglas's life liave deep ramifications for his professional life, especially his career as a Supreme Court Justice."28

The chief lesson that White would have us draw is that from childhood on, Douglas saw himself as a loner, and that he purposefully created, through his writings and his activities, a public image of himself as an individualist. Douglas the environmentalist, Douglas the iconoclast, Douglas the dissenter; all built upon and in turn fostering the persona of the loner who rejected the rigid mores of middle-class society. Yet, as White notes, much of the autobiographical writings are unreliable and contradictory. These writings set out "to present to us one description of a life-the triumph of a man who was true to his mdividuality-and ends up presenting us with quite anotlier description, the trials of a man who could not escape his imdividual torment."29

Since John Marshall's time, the Court has operated under certain collegial patterns designed to develop a consensus among the Justices and present a unified appearance to outsiders. Douglas, however, "seemed to have demonstrated an indifference to those norms almost from the beginnings of his tenure." 30 White locates the origins of this attitude in two events that Douglas described in his inemoirs. The first event occurred during his first term on the bench when Douglas joined the majority in O'Malley $v$. Woodrough ${ }^{31}$ to sustain the constitutionahity of a 1932 statute thiat subjected the salaries of federal judges to federal income tax. ${ }^{32}$ His vote in that case, Douglas later recalled, changed his entire outlook on appropriate judicial behavior:

I decided that I had just voted myself first-class citizenship. The tradition had been that Justices never even voted in public elections. . . I I took a different course. Since I would be paying as heavy an income tax as my neighbor, I decided to participate in local, state, and national affairs. . . . That meant I would register and vote; . . . that I would become immersed in conservation ...; that I would travel and speak out on foreign affairs. ${ }^{33}$

Douglas's second revelation, which Douglas himself characterized as "shattering but ... true," came during a conversation witlı Chief Justice Charles Evans Huglies: "'[Y]ou inust reinember one thing[,]" Huglies said, " '[a]t the constitutional level where we work, ninety per-

\section{Id.}

29. Id. at 40.

30. Id. at 43 .

31. 307 U.S. 277 (1939).

32. See id. at 282. The challenge to the Revenue Act of 1932, Pub. L. No. 154, 47 Stat. 169, rested on Article III, Section 1 of the Constitution, which forbids Congress to reduce a federal judge's salary during that judge's term of office. See U.S. CONST. art. III, $\S 1$.

33. Go EAST, supra note 3, at 466 . 
cent of any decision is emotional. The rational part of us supplies the reasons for supporting our predilections." "34 Douglas claimed that before this conversation, he had "thought of the law in the terms of Moses-primciples chiseled in gramite." 35 He knew that judges had predilections, but had believed that they never allowed "gut reactions" to determine their decisions. Hughes's comment, said Douglas, "destroyed in my mind some of the reverence for immutable principles."36

Yet Professor White notes that to accept Douglas's account of these two episodes at face value is "to ignore his entire career as a legal academic." 37 Although not a constitutional scholar, Douglas lad been one of the leaders of the Reahst movement at Yale, ${ }^{38}$ and certainly knew the ideas of men such as Benjamin Cardozo, Jerome Frank, and Karl Llewellyn-all of whom had discussed the role of personal predilection in judicial decisionmaking. ${ }^{39}$ White contends that, aside from the question of veracity, it appears that Douglas utilized these incidents as a post hoc rationalization of his later behavior. White asserts:

Douglas went on the Court with a rather different calculus, one that rested on the assumption that because law was, at bottom, a collection of the predilections of judges, the political ideology of a Justice was the most significant dimension of his service and should not be suppressed. The remainder of Douglas' career can be seen as consistent with that assumption. Because he believed that law was, fundamentally, nothing more than politics, he took no pains to avoid open participation in public affairs unless, as he put it, "a particular issue was likely to get into the Court, and unless the activity was plainly political or partisai1." ... The doctrinal dimensions of judging, for Douglas, were relatively insignificant; what counted were the results in cases and the political philosophies that those results signified. . . .

....

... That is why legions of coinmentators and the Justices with whom he served found him, although one of the most intellectually talented persons ever appointed to the Court, to be strangely unintercsted in the doctrinal underpinnings of his opinions. ${ }^{40}$

Thus, Professor White finds that because Douglas was result oriented, the political ideology of the judge being the most important factor, he was uninterested in the doctrinal support of his opinions.

34. CoURT Years, supra note 3, at 8.

35. Id.

36. $I d$.

37. White, supra note 26 , at 45 .

38. See Laura Kalman, Legal Realism at Yale, 1927-1960, at 9 (1986).

39. See, e.g., Benjamin N. Cardozo, The Nature of the Judicial. Process (1921); JeROME Frank, LAw AND THE MOdern Mind (1930); Karl N. Llewellyn, A Realistic Jurisprudence-The Next Step, 30 Colum. L. Rev. 431 (1930).

40. White, supra note 26 , at 46,48 . 
It was not a question of whether Douglas could write a sustained analysis - clearly he could. ${ }^{41}$ Rather, he did not consider such analysis necessary. If judges were, in fact, no different than legislators, then the bottom line of their decisions involved only a question of right or wrong, measured against whatever moral or political standards held by that particular judge.

To support his charges, Professor White analyzes Douglas's record in Rosenberg $v$. United States, ${ }^{42}$ as well as his opinions in key cases that expanded the coverage of the Equal Protection Clause. ${ }^{43}$ One of the most controversial cases decided during Douglas's tenure, Rosenberg involved the Rosenbergs' appeal of the death sentence following their conviction for espionage. ${ }^{44}$ The Court went through several twists and turns before finally refusing to hear the appeal; ${ }^{45}$ Felix Frankfurter described the episode as "the most disturbing single experience I have had during my term of service on the Court." 46

Despite Douglas's self-portrayal as a champion of the underdog, fighting against the McCarthyism rampant not only in the country but also on the Court, ${ }^{47}$ subsequent studies showed that Douglas constantly changed his position on whether the Court should accept the appeal for a full hearing. Indeed, his decision to vote against accepting the appeal was the decisive vote. ${ }^{48}$ James Simon, in his generally sympathetic biography of Douglas, agrees that his votes in the Rosenberg case "seemed so inconsistent with his whole judicial approach and philosophy.... Douglas seemed content to let the Rosenbergs go to their execution without even hearing a variety of legal arguments put to the Court by the Rosenberg attorneys." 49

According to White, the Rosenberg case illustrates Douglas's approach to judicial involvement in political questions. Where previous scholars saw Douglas's actions as self-serving or even hypocritical, White

41. See, e.g., Murdock v. Pennsylvania, 319 U.S. 105 (1943); Sunshine Anthracite Coal Co. v. Adkins, 310 U.S. 381 (1940). Professor White found that in these opinions Douglas engaged in a thorough and detailed analysis of commerce clause and due process issues, but he considers them exceptions to the rule. See White, supra note 26 , at 47 n.159.

42. 346 U.S. 273 (1953); see White, supra note 26 , at $48-60$.

43. See infra text accompanying notes $77-87$ for a discussion of these equal protection cases.

44. See Rosenberg, 346 U.S. at 273.

45. See id. at 288 .

46. Felix Frankfurter, Rosenberg Memorandum (June 4, 1953), quoted in Michael E. Parrish, Cold War Justice: The Supreme Court and the Rosenbergs, 82 AM. HIST. REv. 805, 808 (1977).

47. See COURT YeARS, supra note 3, at 78-82. There has been much controversy over the guilt or innocence of the Rosenbergs, as well as the fairness of the legal process that condemned them to death. See, e.g., Louis Nizer, The Implosion Conspiracy (1973); WALTER Schneir \& Miriam Schneir, Invitation to aN InQUest: A New LoOK at the Rosenderg-Sobell CaSe (1968).

48. See Parrish, supra note 46 , at 832.

49. Simon, supra note 4 , at 312 . 
sees them as consistent with his belief that Court deliberations should reflect and further politically conscious ideology.50

In sum, White views Douglas as having evolved into an "antijudge"; a judge who ignored the essential doctrinal and jurisdictional constraints that separate law from politics. He speaks of Douglas as the most outspoken "activist" judge of this century; one who "regarded his task as a Supreme Court Justice to be that of translating his views of social policy into law, with 'law' being the thin veneer of doctrine that somehow made those views acceptable." 51

\section{Douglas AND the Common Law}

All of the criticisms leveled against Douglas derive primarily from his willingness to go outside the allegedly accepted forms of judicial analysis, to reach out to find justification for particular results, and to intrude in areas supposedly the concern of the legislatures. None of the critics pays any attention to the fact that these traits are all part of the common law tradition. If we measure Douglas's record against the experience of the common law, with its emphasis on adaptability and flexibility, we get a much different and much more positive view of Douglas as a judge.

Professor G. Edward White's lament that Douglas ignored the principal modes of modern analysis does not greatly differ from complaints made nearly a century ago against jurists who doggedly adhered to the accepted legal lockstep of the time. In his classic analysis of reform thought at the end of the nineteenth and in the early twentieth century, Morton White described this dominant form of social philosophy as "formahsm." 52 Formalism represented the triumph and the stultification of the ideas of European philosophers such as Hegel, Kant, and Bentham, who emphasized rigid rules and an abstract interpretation of the real world. In jurisprudence, law was viewed as an abstract entity, with immutable values; judges could discover these values by applying the cor-

50. See White, supra note 26 , at 65 . For a defense of Douglas's actions in the case, see William Cohen, Justice Douglas and the Rosenberg Case: Setting the Record Straight, 70 CORNELL L. REv. 211 (1985), responding to Parrish, supra note 46. Cohen views Douglas as acting consistently in light of his belief that the Court should only consider specific questions before it. Douglas opposed granting review when there were no such questions, changed his mind when presented with new facts, and then retreated when it appeared that these would not affect the results. See also Michael E. Parrish, Justice Douglas and the Rosenberg Case: A Rejoinder, 70 CORNELL L. REV. 1048 (1985) (rejecting Cohen's views on Douglas's motives for withdrawing his memorandum in support of granting certiorari and arguing that Douglas, as in other controversial cases, "attempted to straddle the issues" in order to protect his liberal self-image while allowing treasonous behavior to be punished).

51. White, supra note 26 , at 80 .

52. Morton White, Social Thought in America: The Revolt Against Formalism (1949). 
rect rules of analysis. ${ }^{53}$ This view of law also assumed a strong correlation with ethics; the discovery of the correct legal principle to apply in a particular case would mean that the correct moral judgment had also been made. ${ }^{54}$ The problem with formalism, however, was that it bore no relation to reality. This defect was exposed by Oliver Wendell Holmes, Jr. in The Common Law. 55

Writing after sixteen years on the Supreme Judicial Court of Massachusetts, Holmes attacked the idea that "a given word or even a given collocation of words has one meaning and no other. A word generally has several meanings, even in the dictionary. You have to consider the sentence in which it stands to decide which of those meanings it bears in the particular case ...."56 The "law" itself, therefore, could never be precisely defined, and Holmes declared that the study of law could do little more than point to certain outcomes: "The prophecies of what the courts will do in fact, and nothing more pretentious, are what I mean by the law." 57

Holmes's realism, as Morton White suggested, consisted of "rejecting the view that law is an abstract entity present as the meaning of a given statute, waiting to be found by a judge. On the contrary it is, in great measure, made by the judge." 58 This is clear in Holmes's famous battle-cry against legal formalism with which he began his Lowell lectures:

The life of the law has not been logic: it has been experience. The felt necessities of the time, the prevalent moral and political theories, intuitions of public policy, avowed or unconscious, even the prejudices which judges share with their fellow-men, have had a good deal more to do than the syllogism in determining the rules by which men should be governed. The law embodies the story of a nation's development through many centuries, and it cannot be dealt with as if it contained only the axioms and corollaries of a book of mathematics. 59

53. I do not wish to imply that Professor White calls for, or holds as an ideal, a rigid and doctrinaire form of analysis as the only legitimate means of constitutional interpretation. But in charging Douglas with "reject[ing] both of the principal twentieth-century devices to constrain subjective judicial lawmaking: fidelity to constitutional text or doctrine, and institutional deference," White, supra note 26 , at 18 , I believe that White has imposed a formalistic standard not dissimilar in its belief in a "right" way to that to which Justice Oliver Wendell Holmes, Jr. objected.

54. See id. at 65 ("[Douglas] would hikely have described Rosenberg, or any other case, as simply an opportunity for the 'right' values to triumph.").

55. Oliver W. Holmes, JR., The Common LaW (1881).

56. Oliver W. Holmes, JR., The Theory of Legal Interpretation, in Collected Legal PAPERS 203 (1920).

57. Oliver W. Holmes, JR., The Path of the Law, in Collected Legal PAPERs, supra note 56 , at $167,173$.

58. WHITE, supra note 52 , at 8.

59. HoLmes, supra note 55 , at 1 . 
The Lowell lectures dealt with the common law-the means by which Anglo-American law has kept in step with social and economic realities for the past several centuries. It has been said that the common law:

is not a codification of exact or inflexible rules for human conduct, ... but is rather the embodiment of broad and comprehensive unwritten principles, inspired by natural reason and an innate sense of justice ....

$\ldots$

The inherent capacity of the common law for growth and change is its most significant feature. ${ }^{60}$

Although legislatures may statutorily amend or even abolish common law rules, it is debatable whether, and to what extent, courts themselves should develop new law when confronted with competing principles of social policy. Those who advocate judicial restraint argue that the legislative branch alone sliould promulgate new laws, and that the judges have no role in this activity.61 The opposing, or "activist," view was stated by Justice Marcus Kaufman of the California Supreme Court: "The courts are the custodians of the common law-not the economists, or the legislators, or even the law professors. We abdicate that duty when we abjure decision of common law questions under the guise of "deference" to the political branches." 62 This view has also been urged by legal scholars such as Arthur Corbin, who wrote:

It is the function of our courts to keep the doctrines up to date with the mores by contimual restatement and by giving them a continually new content. This is judicial legislation, and the judge legislates at his peril. Nevertheless, it is the necessity and duty of such legislation that gives to judicial office its highest honor; and no brave and honest judge shirks the duty or fears the peril. ${ }^{63}$

This description seems to capture the charges against Douglas. Indeed, instead of portraying Douglas negatively, they allow us to see Douglas in a different and perhaps more favorable light: as a common law judge on the nation's highest court.

Most simply, the common law is judge-made law; a body of general rules and precedents that grow out of specific cases, which judges then

60. Rodriguez v. Bethlehem Steel Corp., 525 P.2d 669, 676 (Cal. 1974).

61. See, e.g., Webster v. Reproductive Health Servs., 492 U.S. 490, 532 (1989) (Scalia, J., concurring) (charging that the decision has "needlessly ... prolong[ed] this Court's self-awarded sovereignty over a field where it has little proper business, since the answers to most of the cruel questions posed are political and juridical").

62. Foley v. Interactive Data Corp., 765 P.2d 373, 417 (Cal. 1988) (Kaufman, J., concurring and dissenting).

63. Arthur L. Corbin, The Offer of an Act for a Promise, 29 YALE L.J. 767, 771-72 (1920) (footnote omitted). 
apply to current cases with similar fact situations. The common law tradition strove for a generalized rule, which would allow judges flexibility in individual cases; stare decisis, by which prior decisions governed present cases, was never a rigid doctrine. ${ }^{64}$ Just as the courts of equity injected compassion into the rigidity of law, so could a coininon law judge tailor the law to ineet the circuinstances of the present case. ${ }^{65}$

Although statutory law always overrode common law, in the nineteenth and early twentieth centuries legislation usually focused on narrow, specific targets-coinpany charters, tariffs, funding for a canal, defining criminal activity, and other such issues. This allowed judges some leeway in their interpretation of statutes when the issues were broader than those narrowly defined by the legislatures. ${ }^{66}$ This did not mean, however, that they could decide cases on whims; the glory of the coinmon law lay in its combination of a general systein of overriding rules that nonetheless allowed growth and change to meet new needs. ${ }^{67}$

Thus, under the common law, judges inake law, not just interpret it. This raises questions as to whether common law flexibility is legitinate in constitutional interpretation. ${ }^{68}$ Some commentators beheve that judges are bound by the original intent of the Framers, and that constitutional interpretation consists of nothing more than discovering that intent. ${ }^{69}$ Others view the common law as a ineans by which social inequities can be remedied, even within the confines of the Constitution. ${ }^{70}$

The common law judge, then, operates within a body of general rules and principles, but is ever mindful that as social and economic conditions change, the law must so adapt. When conditions warrant, the

64. See, e.g., United States v. Connor, 926 F.2d 81, 83 (1st Cir. 1991) ("[S]tare decisis is not a rigid, inflexible rule.").

65. See Grant Gilmore, The Ages of American Law (1977) (describing the rise of the common law tradition in the United States).

66. Judges, of course, operate in a legal system that combines both statutory and common law; however, statutory law has assumed a far more dominant position in recent years. The survival, and indeed even growth, of common law in this condition is explored in GuIDo Calabresi, A Common LAW FOR THE AGE OF STATUTES 163-66 (1982).

67. See LAWRENCE M. Friedman, A History of American LAW 17-25 (1973) (discussing how judges altered the common law of the eighteenth century to meet the rapidly changing conditions of nineteenth-century America); Morton J. Horwitz, The Transformation OF AMERICAN LAW, 1780-1860 (1977) (same).

68. See Randall Bridwell \& Ralph U. Whitten, The Constitution and the ComMON LAW 136 (1977).

69. The literature on this topic is extensive and rapidly expanded during the 1980s. For the views of one of the leading exponents of original intent, see Edwin Meese III, Construing the Constitution, 19 U.C. DAVIS L. REV. 2 (1985).

70. See, e.g., Charles M. HaAr \& Daniel W. Fessler, The Wrong Side of the Tracks 227-33 (1986) (advocating using the doctrine of equal services to address the present-day problem of inequity in commercial services and facilities). 
common law judge thus feels free to change or even abandon precedent to create new law that addresses the problems at hand. This judicial lawmaking can take place in a court of common pleas or even in the United States Supreme Court.

\section{DOUGLAS AND RESUltS}

The charge of judicial activism put forth by White and others ignores an important fact: Douglas was often "right,"71 and in a way that won the support not only of his colleagues on the bench, but also of the American public. Only the academy has failed to appreciate fully the approach Douglas brought to the bench.

Erwin N. Griswold, in his Foreword to the Wolfman analysis of Douglas's tax opmions, ${ }^{72}$ recalled that about a year after Douglas took his seat on the Court, he wrote the opinion in Helvering $v$. Clifford, ${ }^{73}$ which Griswold describes as "surely one of the strongest pro-government tax cases in the books." "74 But Griswold goes on to say:

From an Olympian point of view, the result may well have seemed desirable. But there was little, if anything, in the statute to support it. Nor was it the culmmation of a series of decisions, slowly etching out a new ground in the law. Even today, it seems to have been a rather strong case of judicial law-making. Ultimately, it has, on the whole, worked out quite well. However, there was at first an enormous amount of litigation. Several years later, the Treasury undertook to clarify the situation with comprehensive regulations. Finally, in 1954, fourteen years after the Clifford decision, Congress enacted detailed statutory provisions .... It may well be that this result never would have been reached without the bold action of the Supreme Court in the Clifford case. ${ }^{75}$

Professor White further asserts that Douglas suffered an "unwillingness to buttress the results he reached in cases by resort to the common analytical techniques employed by twentieth-century Justices as justifica-

71. I use the word "right" in the same sense that Professor White uses it-that the observer intuitively recognizes the correctness of a particular question or answer given the fact situation in the larger context of contemporary moral views. See White, supra note 26, at 60-65.

72. Erwin N. Griswold, Foreword to WolfmaN, supra note 24, at ix.

73. 309 U.S. 331 (1940). Clifford involved a taxpayer who created a short-term trust over which he exercised full control as trustee, although the income went to his wife. The Commissionet of Revenue ruled that because the taxpayer had established the trust merely to avoid taxes, and had in effect retained full control of the assets, he must therefore bear the tax consequences. Justice Douglas ruled that since section 61(a) of the Revenue Act of 1934 did not address the issue of shortterm trusts with great clarity, the trier of fact could determine whether a trustee had, as a practical matter, rights associated with ownership, and, if so, the accruing tax liability. See id. at 338.

74. Griswold, supra note 72 , at $\mathrm{x}$.

75. Id. at $\mathrm{x}$-xi (footnote omitted). There are only a few citations to proper cases in the decision, but Justice Douglas's analysis of the meanings of property rights and ownership are by no means fanciful or farfetched. 
tory devices."76 Professor White uses two cases to illustrate Douglas undertaking novel doctrinal analysis without extensive justificatory effort: Skinner v. Oklahoma ${ }^{77}$ and Griswold v. Connecticut. ${ }^{78}$ According to White, both decisions were:

doctrinally audacious opinions whose innovativeness was cryptically, even assertively presented; both involved end runs around apparently insurmountable analytical barriers; and both touched upon a themethe decision to procreate and thus to pass on one's legacy of individuality to one's progeny and hence to posterity-that touched deep currents in Douglas' life. ${ }^{79}$

Skinner involved an Oklahoma statute that mandated sterilization for habitual criminals. ${ }^{80}$ Justice Holmes, in an earlier opinion supporting a Virginia sterilization law for persons witl hereditary imbecility or insanity, had seemingly cut off any equal protection argument by deriding it as "the usual last resort of constitutional arguments."81 The abuse of substantive due process im the 1920s and 1930s had made that avenue equally unattractive, especially after the Court, in West Coast Hotel Co. v. Parrish, ${ }^{82}$ abjured using the Fourteenth Amendment to second-guess legislative judgments.

Douglas, as White points out, was faced with a jurisprudential environinent that seemingly negated both due process and equal protection arguments. Yet, he cut through the Gordian knot by noting that the law did not apply equally to all felons because it made an exception for embezzlers. ${ }^{83}$ This opened the door to equal protection analysis, and Douglas charged through. He identified the right to procreate as a fundamental right, and concluded that any legislation restricting that right would be subject to strict judicial scrutiny. ${ }^{84}$ Because the Oklahona law did not apply equally to all, it thus failed the constitutional test. 85

White denounces Douglas's opinion in several ways: that the Equal Protection Clause lay dormant, if not moribund, and was thus an inappropriate device to guarantee such rights; that the Court had never before identified procreation as a fundamental right; that Douglas did not offer a single cite to justify this decision; that he connected fundamental

76. White, supra note 26 , at 65 .

77. 316 U.S. 535 (1942).

78. 381 U.S. 479 (1965).

79. White, supra note 26 , at 66 .

80. Okla. Stat. ANN. tit. 57, $\$ \S 171-195$ (West 1937).

81. Buck v. Bell, 274 U.S. 200, 208 (1927).

82. 300 U.S. 379 (1937).

83. See Skinner, 316 U.S. at 538-39, 541-42; White, supra note 26 , at $66-68$.

84. See Skinner, 316 U.S. at 541.

85. See id. at 541-42. 
rights to a strict scrutiny standard without any support for this assertion; that he pronounced the "invidious discrimination" in the law's enforcement as its chief evil; and that all this was "advanced without any textual or doctrinal support." $\$$

Yet Douglas decided the case correctly, and in so doing breathed life back into the Equal Protection Clause. As White hinself notes, in the twenty-three years between Skinner and Griswold, the Court began to make more substantive judgments on equal protection claims, and it adopted the same analytic model that Douglas created in Skinner ${ }^{87}$

But why was it bad when Douglas engaged in that type of analysis in 1942? Was it because, as Professor White clains, Douglas had made this analysis without "any textual or doctrinal support"?88 Does it then become acceptable for another justice to apply that model in $1956^{89}$ or in $1963^{90}$ because now there is a precedent for it—namely, Douglas's opinion in Skinner?

If one case represents Douglas's willingness to be creative in reaching a particular result, it is surely Griswold. ${ }^{91}$ Griswold involved the challenge of a Comstock-era Comecticut statute that completely prohibited the use of contraceptive devices. Because the law applied to all persons, an equal protection claim seemed precluded. With a liberty argument under the Due Process Clause still apparently blocked by the legacy of the 1930s, ${ }^{92}$ Douglas had to engage in a highly creative and controversial analysis that found "emanations" and "penumbras" 93 in various guarantees of the First, Third, Fourth, Fifth, and Ninth Amendments to create a constitutionally protected zone of privacy. ${ }^{94}$ From this

86. White, supra note 26 , at 68 .

87. See id. at 68-69.

88. Id. at 68 .

89. See Griffin v. Illinois, 351 U.S. 12 (1956) (requiring that indigent defendants be furnished with trial transcripts; Justice Black wrote the Court's opinion utilizing an equal protection analysis).

90. See Douglas v. California, 372 U.S. 353, 355 (1963) (Justice Douglas wrote the Court's brief opinion requiring states to appoint counsel for indigent defendants at the first appeal stage; he cited Griffin for the equal protection analysis involving poverty as an invidious distinction.).

91. Griswold v. Connecticut, 381 U.S. 479,484 (1965).

92. See, e.g., Hammer v. Dagenhart, 247 U.S. 251 (1918); Muller v. Oregon, 208 U.S. 412 (1908); Lochner v. New York, 198 U.S. 45 (1905); Allgeyer v. Louisiana, 165 U.S. 578 (1897).

93. Griswold, 381 U.S. at 484. Justice Douglas, however, did not invent the idea of a penumbral doctrine. A noted law dictionary traces it to an early federal eminent domain decision, Kohl v. United States, 91 U.S. 367 (1875). BLACK's LAw DictionaRY 1135 (6th ed. 1990). Further, Justice Holmes used the notion of "the penumbra of the Fourth and Fifth amendments" nearly 40 years before Griswold in his dissent in the subsequently discredited wiretap case, Olmstead v. United States, 277 U.S. 438, 469 (1928). For a discussion of penumbral doctrine in prior legal reasoning, see Dorothy J. Glancy, Douglas's Right to Privacy: A Response to His Critics, in LEGACY of Justice DoUglas, supra note 9, at 160-62.

94. See Griswold, 381 U.S. at 484. 
he concluded that a "right" to privacy existed-a right "older than the Bill of Rights."95 In this context, the right to privacy was imphicated because the association of marriage was "intimate to the degree of being sacred."96 Thus, Connecticut's invasion of this right to privacy was not constitutionally permissible. Douglas did not engage in an extended analysis or elaboration of the results in Griswold; "the justification for the results was ultimately that they were overwhelmingly morally 'right." "97

According to Professor White, "the significance of Douglas' Griswold opinion was not that it chose the rubric of privacy on which to justify its result, but that it responded to what appeared to be a doctrinal impasse by simply creating constitutional doctrine on the spot, as Douglas had done in Skinner."98 White, it should be added, concedes that the basic questions asked in both cases had obvious answers, the very answers provided by Douglas. ${ }^{99}$ The only difficulties in reaching these answers, according to White, "were analytical, created by the presence of awkward doctrinal barriers. Douglas simply disregarded those barriers and created some new doctrine."100

Douglas recognized that his reasoning and mode of argument were often unconventional. Rather than look merely to the relevant precedents, Douglas, like all good common law judges, contemplated all the facts surrounding a case. ${ }^{101}$ The Douglas opinion in Griswold can best be described as "dehiberately open-textured and suggestive, rather than closely argued and defimitive," 102 but "[t]he fact that this type of impressionistic reasoning is unconventional does not necessarily mean that it is wrong."103

95. Id. at 486.

96. Id.

97. White, supra note 26 , at 71 .

98. Id. at 70 .

99. "Would we allow the police to search the sacred precincts of marital bedrooms for tell-tale signs of contraceptives?" and "Should we allow the state to sterilize the chicken thief but not the embezzler?" should, of course, be answered in the negative.

100. White, supra note 26 , at 71 .

101. Justice Brandeis, for example, lectured his brethren that " $t]$ he judgment should be based upon a consideration of relevant facts, actual or possible-ex facto jus oritur. That ancient rule must prevail in order that we may have a system of living law." Adams v. Tanner, 244 U.S. 590, 600 (1917) (Brandeis, J., dissenting). For Dorothy Glancy's comparison of Douglas's examination in Griswold of "all sorts of legal rules and decisions in order to find the principle underlying them" to what Louis Brandeis and Samuel Warren did in their pioneering 1890 article on the common law right to privacy, Samuel Warren \& Louis D. Brandeis, The Right to Privacy, 4 HARv. L. Rev. 193 (1890), see Glancy, supra note 93, at 162.

102. Glancy, supra note 93 , at 162 .

103. Id. Professor Jan Deutsch of Yale Law School clerked for Potter Stewart during the 1962 Term, and he reports great frustration with Justice Douglas's opinions. He would meet with Douglas's clerk, Jerome Falk, and would say "Jerry, it doesn't work. It does not work!" Then Falk would show him that it did work, because Douglas did not take just the bare holdings, but all the glosses 
Commentators have been troubled with Griswold since its inception. Dinesh D'Sousa could find no right to privacy in the Constitution: "Hold it up to the light, read it backwards in the unirror-still nothing." 104 Robert Bork condemned Douglas's analysis, claining that the penumbral "right of privacy strikes without warning. It has no intellectual structure to it so you don't know in advance to what it applies."105 Thomas Emerson worried about "the vagueness of the concept, and the general lack of precise standards"; ${ }^{106}$ while Paul Kauper condemned the "accordion-like qualities of the emanations-and-penumbra theory."107

And yet, Americans intuitively believe in a right to privacy, and that it ought to be constitutionally protected. ${ }^{108}$ Years ago Justice Louis D. Brandeis declared: "The makers of our Constitution . . . sought to protect Americans in their behefs, their thoughts, their emotions and their sensations. They conferred, as against the government, the right to be let alone-the most comprehensive of rights and the right most valued by civilized men." 109 Privacy is a value shared by liberals and conservatives. Although both groups may question the analysis used to support privacy as a constitutional right, most agree with the result. And results are exactly what Douglas sought; he never pretended to be anything other than a results-oriented judge.

Only results can explain Douglas's rationale in Levy v. Louisiana, ${ }^{110}$ in which the Court found an equal protection violation in a state law that denied unacknowledged illegitimate children the right to recover for the wrongful death of their mother. ${ }^{111}$ Although Douglas's opinion hinted

that went with earlier opinions, and frons those wove his own conclusions. "Most legal scholars at Yale do not think that glossing nuatters," Deutsch concluded, "but do you know how hard it is to do what Douglas did and produce a coherent opinion?" Interview with Jan Deutsch, in New Haven, Conn. (June 28, 1988).

104. Dinesh D'Sousa, The New Liberal Censorship, PoL'y REv., Fall 1986, at 8, 13.

105. Robert Bork, Foreword to GARY L. MCDOwEll, The Constitution AND ContempoRARY CONSTITUTIONAL THEORY, at $x$ (1985).

106. Thonas I. Emerson, Nine Justices in Search of a Doctrine, 64 MICH. L. REv. 219, 230 (1965).

107. Paul G. Kauper, Penumbras, Peripheries, Emanations, Things Fundamental and Things Forgotten: The Griswold Case, 64 Mich. L. REv. 235, 253 (1965). For a defense of Justice Douglas's reasoning, and its ties to prior Court decisions and reasoning, see Glancy, supra note 93, at 160. 62; see also Adler, supra note 11, at 1588-95 (explaining Justice Douglas's privacy opinions in the context of his concept of individuality and view of the Bill of Rights).

108. See Louis Harris and associates \& Alan F. Westin, The Dimensions of Privacy: A National Opinion Research SuRvey of AtTitudes Toward Privacy 15 (1981) (reporting that more than three-fourths of the surveyed population believe a right of privacy should be on the same protected level of life, liberty, and the pursuit of happiness).

109. Olmstead v. United States, 277 U.S. 438,478 (1928) (Brandeis, J., dissenting).

110. 391 U.S. 68 (1968).

111. Id. at 71. In a companion case, Justice Douglas wrote for the Court in holding another Louisiana statute violative of the Equal Protection Clause because it denied a mother recovery for 
at both a simple rationality test and at heightened scrutiny, he did ask the right questions:

We start from the premise that illegitimate children are not "non-persons." They are humans, live, and have their being. . . . The rights asserted here involve the intimate, familial relationship between a child and his own mother. When the child's claim of damage for loss of his mother is in issue, why, in terms of "equal protection," should the tortfeasors go free merely because the child is illegitimate? Why should the illegitimate child be denied rights merely because of his birth out of wedlock? He certainly is subject to all the responsibilities of a citizen, imcluding the payment of taxes and conscription under the Selective Service Act. How under our constitutional regime can he be denied correlative rights which other citizens enjoy?112

Compare the common sense and humanity of this decision to that in Labine $v$. Vincent ${ }^{113}$ three years later when a new majority upheld a Louisiana law that subordinated the rights of acknowledged illegitimate children to those of other relatives in intestate succession. One passage in Justice Black's brief opinion suggested that there might not be even a mimimal rationality review because "[a]bsent a specific constitutional guarantee, it is for [the] legislature, not the life-tenured judges of this Court, to select from aniong possible laws." 114

Results by themselves, of course, are not and should not be the sole criterion by which we evaluate judicial performance. Much can be said in favor of the ability to reason from text and precedent, and to defer to the judgment of the pohitically elected branches of government im pohicy determination. But it is not necessarily anti-democratic for non-elected judges to make pohcy, and this is especially true im a common law setting.

The law needs both continuity and change; it must provide stability through solid limks to the past, yet it must also be responsive to new social and economic conditions. Although legislatures, through legislation, provide for both continuity and change, they do so primarily in gross; that is, the laws they write determine major pohcies. How these

the wrongful death of an illegitimate child while allowing recovery in the deaths of legitimate children. See Glona v. American Guar. \& Liab. Ins. Co., 391 U.S. 73 (1968).

112. Id. at 70-71 (citation omitted).

113. 401 U.S. 532 (1971), overruled by Trimble v. Gordan, 430 U.S. 762 (1977).

114. Id. at 538-39 (citation omitted). Since then the Court has followed what might at best be called a wavering line in cases involving the rights of illegitimate children. See Weber v. Aetna Cas. \& Sur. Co., 406 U.S. 164, 171-72 (1972) (following Levy in striking down a Louisiana workman compensation statute giving preference to legitimate children in cases of parental disability); Mathews v. Lucas, 427 U.S. 495, 512 (1976) (following Labine in upholding different presumptions under the Social Security Act for legitimate and illegitimate children attempting to receive parents' benefits); Mills v. Habluetzel, 456 U.S. 91, 97-101 (1982) (applying equal protection analysis to differential time limits imposed on claims for child support for legitimate and illegitimate offspring). 
are actually implemented, how they are applied in fine, is left to the courts. As Guido Calabresi has argued, this is appropriate. According to Calabresi, the common law function of courts today is "no more and no less than the critical task of deciding when a retentionist or a revisionist bias is appropriately apphed to an existing statutory or common law rule." 115 Although Calabresi is aware of the problens that an activist court may cause, he also points out how avoidance of creating new rules niay also stifle the law. ${ }^{116}$ Judges who defer to outrageous or no longer relevant judicial precedents, or to inconsistent or unconscionable legislative actions, out of a desire for doctrinal consistency are rarely considered great judges by the history books.

For example, if any Justice of the Supreme Court in this century might be considered the paragon of "fidelity to constitutional text or doctrine, and institutional deference," 117 it would certainly be Felix Frankfurter. For the twenty-three years he occupied the "scliolar's seat"118 on the Court, Frankfurter wrote law review articles that masqueraded as judicial opinions, and carried judicial restraint to the point of judicial abdication. Yet Frankfurter's reputation for jurisprudence has never been high with scholars, and succeeding justices have largely ignored his opinions. ${ }^{119}$

There is no question that Frankfurter's opinions are more scholarly, more in the mode of analysis described by Professor White as the "norm," 120 and inore deferential to the legislature. If we evaluate Frankfurter's opinions by their impact on American constitutional law, however, they are insignificant. ${ }^{121}$ Douglas, by acting as a coinmon law

115. CALABRESI, supra note 66 , at 164 .

116. See id. at 75; see also Melvin A. Eisenberg, The Nature of the Common Law 5 (1988) (arguing that "in many cases the flexible form of a judicial rule is preferable to the canonical form of a legislative rule").

117. White, supra note 26 , at 18 (referring to Justice Douglas).

118. The scholar's seat was the common appellation used in the 1930s and 1940s to refer to the seat held by Frankfurter and his predecessors. Horace Gray, who taught at the Harvard Law School, held the seat from 1881 to 1902; he was succeeded by Oliver Wendell Holmes, Jr., who served until 1932. The scholarly Benjamin Nathan Cardozo replaced Holmes, and Cardozo was replaced by Professor Felix Frankfurter in 1939.

119. See, e.g., West Virginia State Bd. of Educ. v. Barnette, 319 U.S. 624 (1943) (overruling Minersville School Dist. v. Gobitis, 310 U.S. 586 (1940)); Mapp v. Ohio, 367 U.S. 643 (1961) (overruling Wolf v. Colorado, 338 U.S. 25 (1949)); Baker v. Carr, 369 U.S. 186 (1962) (overruling Colegrove v. Green, 328 U.S. 549 (1946)).

120. White, supra note 26 , at 43 .

121. See Gerald Gunther, Constitutional Law (11th ed. 1985). In this widely used constitutional law text, the author includes among his principal cases nine Douglas opinions for the Court and only one written by Frankfurter. In nonprincipal cases, Douglas's opinions are referred to far more frequently than Frankfurter's. In a major criminal procedure text, STEPHEN A. Saltzburg, American Criminal Procedure: Cases and Commentary (2d ed. 1984), only one opinion by Frankfurter is included-a Fourth Amendment case, on which Frankfurter consid- 
judge, by asking the right questions, and by engaging in unorthodox analysis, reached morally correct results far more often.

For example, in 1959, the Warren Court considered a civil case regarding whether city health inspectors could enter premises without a search warrant. ${ }^{122}$ Nearly everyone on the Court thought of it as a simple question because the Fourth Amendment had previously been limited to criminal situations. ${ }^{123}$ Frankfurter, who considered the Fourth Amendment as his private preserve, was assigned to write the majority opinion. He buttressed it with copious references to prior rulings to show that the right to a search warrant did not apply to civil searches. ${ }^{124}$

Douglas disagreed, and requested that his clerk, Charles Miller, work on a dissent. Miller retrieved a multitude of books from the library and pored through numerous cases; he was unable, however, to find support for Douglas's dissent. An angry and frustrated Douglas told Miller to "[b]ring in all the books you got, and let me see what I can do."125 For three days Douglas stayed in his office, working at the materials Miller had compiled. At the end of that time he "scratched out" ten pages that, according to Miller, "bowled me over. It was the most persuasive thing I had seen in my life."126

Douglas circulated the draft, and three justices (Warren, Black, and Brennan) immediately switched their vote. Justice Whittaker almost joined Douglas, but after intense lobbying by Frankfurter, remained with the majority through a one-paragraph concurrence. ${ }^{127}$ Eight years later, the Court overruled the Frankfurter opinion and adopted the Douglas view that a search conducted by the government-either by criminal division or civil officials-is still a search and subject to Fourth Amendment protections. ${ }^{128}$ Whereas Frankfurter's formalistic analysis led to a

ered himself the Court's leading authority. Id. at 329. That case, Wolf v. Colorado, 338 U.S. 25 (1949), held that the exclusionary rule did not apply to the states; the decision was overruled in Mapp v. Ohio, 367 U.S. 643 (1961). Justice Douglas never claimed any special expertise in criminal procedure, but, according to one scholar, he had an enormous impact on this area of the law. See Stephen B. Duke, William $O$. Douglas and the Rights of the Accused, in LEGACY OF JUSTICE DougLAS, supra note 9, at 140-42. Duke notes a number of Douglas's decisions that are still good law, and which are part and parcel of the Warren Court's "due process revolution." These include Argersinger v. Hamlin, 407 U.S. 25 (1972), Boykin v. Alabama, 395 U.S. 238 (1969), Griffin v. California, 380 U.S. 609 (1965), and Douglas v. Califomia, 372 U.S. 353 (1963).

122. Frank v. Maryland, 359 U.S. 360 (1959).

123. See id. at $365-66$.

124. See id. at 362-65.

125. Interview with Charles Miller, in Washington, D.C. (Mar. 2, 1989).

126. Id. For Douglas's dissent, see Frank, 359 U.S. at 374.

127. Interview with Charles Miller, supra note 125. For Whittaker's concurrence, see Frank, 359 U.S. at 373.

128. See Camara v. Municipal Court, 387 U.S. 523 (1967); See v. Seattle, 387 U.S. 541 (1967). 
bad result, Douglas's unconventional analysis both asked the right question and reached the right answer.

Vern Countryman reminds us that scholarship by itself is no guarantee that an opinion will be either sound or just, and that in any case, scholarship "is no substitute for common sense."129 Years ago Max Radin commented that judges decide on a result that seems correct. The necessity of writing an opinion to explain this result gives them the "opportunity of working their judgment backward, front a desirable conclusion to one or another of a stock of logical premises."130 Douglas, a close friend of Radin, shared this view. In response to critics who charged that his opinions lacked scholarship, he said that " for those who liked the result it was scholarship." "131

\section{Douglas and His Role on the Court}

Even if Douglas can be better understood as a common law judge, the question remains whether the common law approach is an acceptable form of jurisprudence on the nation's highest court, and whether it is a legitiniate means of constitutional interpretation. For those like Edwin Meese who behieve that there is only one correct interpretation of the Constitution-the view intended by its Framers ${ }^{132}$ - fidelity to constitutional text and imstitutional deference is the only acceptable jurisprudence. Yet one need not share Meese's extreme views to argue that a common law approach is inappropriate when deahing with the Constitution.

In terms of historical perspective, however, the Supreme Court has been a common law as well as a statutory and constitutional court for much of its history. Until Erie Railroad Co. v. Tompkins, ${ }^{133}$ a good por-

129. Vern Countryman, Scholarship and Common Sense, 93 HARV. L. REV. 1407, 1409 (1980). Countryman, in response to a comment that Justice Douglas never developed his argument, said:

Well, I've heard that criticism all my life, and frankly I don't think there's a helluva lot to it. For instance, in the Dennis case [Dennis v. United States, 341 U.S. 494 (1951)], he didn't ring all the chimes on the clear and present danger test, like Frankfurter would have done. He just said that anybody who thinks these birds are a clear and present danger is in the grip of liysteria .... That was all that needed to be said. There had been enough chimes rung on clear and present danger .... So he didn't think it was necessary to run through the thing again.

Interview witl Vern Countryman, Professor of Law, Harvard Law School, in San Francisco, Cal. (Aug. 29, 1988).

130. Max Radin, The Theory of Judicial Decisions: Or How Judges Think, 11 A.B.A. J. 358 (1925).

131. Countryman, supra note 129 , at 1409 n.14 (quoting Justice Douglas). Justice Douglas told another friend, Eric Severeid, that judges who write 58 page opinions do so because they do not stick to the Constitution. Glancy, supra note 93 , at 175 n.58.

132. See Meese, supra note 69 , at 26.

133. 304 U.S. 64 (1938). 
tion of the Court's docket involved such traditional common law cases as contract and negligence. In his excellent study of the Supreme Court during the Progressive era, John Semonche concluded that the Court responded to the changes and challenges of the time in the finest common law tradition. ${ }^{134}$ Moreover, even if we accept the notion that constitutional interpretation must be closely tied to the text, there are many gaps in that eighteenth-century text. As Justice Jackson once explained, the burden of judicial interpretation is to translate "the majestic generalities of the Bill of Rights, conceived as part of the pattern of liberal government in the eigliteentli century, into concrete restraints on officials dealing with the problems of the twentieth century."135 Translating "majestic generalities" sounds more like common law practicality than like wooden fidelity to text and doctrinal niceties.

One wonders whether many of the great changes would liave occurred had a majority of the Supreine Court followed the Frankfurter scliool. For instance, although Frankfurter did not sympathize with racial segregation, he questioned the Court's ability to apply the Equal Protection Clause to reverse Plessy v. Ferguson. ${ }^{136}$ Douglas, who liad pioneered the resurrection of the Equal Protection Clause, had no qualms over the results. Moreover, the two-step analysis he formulated in Skinner ${ }^{137}$ made perfectly good sense, and he pushed his colleagues toward Brown from the time the segregation cases were first heard by the Court. ${ }^{138}$

Could the Warren Court have launclied its great revolution in due process had it slavishly adhered to precedent in its interpretation of the Fourth, Fiftli, and Sixth Amendinents? Common sense tells us that the restraints on potice misbehavior ought to be comparable regardless of whether such action is pursuant to federal or state authority. Similarly, when the apportionment issue was first heard by the Court in Colegrove

134. See John E. Semonche, Charting the Future: The Supreme Court Responds to A Changing Societr, 1890-1920, at 426-34 (1978).

135. West Virginia State Bd. of Educ. v. Bamette, 319 U.S. 624,639 (1943).

136. 163 U.S. 537 (1896). For Frankfurter's reluctance to proceed in Brown v. Board of Education, 347 U.S. 483 (1954), see RICHARD KLUGER, SIMPLE JUSTICE 668-70 (1976). Frankfurter asked his law clerk, Alexander M. Bickel, to determine if the Brown result could be justified in terms of history and original intent; Bickel found that this was not possible. Bickel later published the result of his research; see Alexander M. Bickel, The Original Understanding and the Segregation Decision, 69 HARV. L. REV. 1 (1955).

137. See Skinner, 316 U.S. at 541-42; see supra text accompanying notes $80-85$.

138. See William O. Douglas, Memorandum for the File, in The Douglas LetTers 165-67 (Melvin I. Urofsky ed., 1987). 
v. Green, ${ }^{139}$ Frankfurter lectured his brethren to avoid the "political thicket," and warned them that the courts had neither the power nor the wisdom to resolve the problem. ${ }^{140}$ Black, Douglas, and Murphy dissented in that first case, ${ }^{141}$ and time proved them right. Sixteen years later in Baker v. Carr, ${ }^{142}$ the Court declared the question justiciable ${ }^{143}$ over Frankfurter's bitter protest; ${ }^{144}$ two years later, in Reynolds $v$. Sims, ${ }^{145}$ the Court required that all states apportion their legislatures on an equitable basis. ${ }^{146}$

Between Baker and Reynolds, however, Douglas answered one of Frankfurter's major objections-that the courts could not fashion judicially discoverable and manageable standards. In a case that involved the Georgia county unit system, Justice Douglas set forth a formula that not only provided judicial guidance, but caught the popular imagination as well-"one person, one vote."147 Despite Justice Harlan's complaint that the formula "flies in the face of history," 148 one senses the rightness of that decision, as well as the common sense of this and the other apportionment decisions-despite their alleged lack of analysis and fidelity to text.

Douglas has long been considered an activist in that he willingly reached out to decide issues and to expand the reach of constitutional protections. However, Douglas viewed himself as a strict constructionist; the most dranatic example of this is his (and Justice Black's) absolutist interpretation of the First Amendment Speech Clause149_"Congress shall make no law . . . abridging the freedom of speech . . .."1so Although an absolutist position may be an excuse to avoid the problems of analysis in balancing individual freedom against social order, it also provides a consistency often lacking in First Amendment analysis. Thomas Einerson, one of the nation's leading scholars on freedom of speech, lauded Douglas's use of the First Amendinent "as a counter to

139. 328 U.S. 549 (1946) (denying declaratory relief to petitioners who claimed that the voting districts in Illinois lacked compactness and equality; Court held that this was a nonjusticiable political question).

140. See id. at 556.

141. See id. at 566 (Black, J., dissenting).

142. 369 U.S. 186 (1962).

143. See id. at 209.

144. See id. at 266 (Frankfurter, J., dissenting).

145. 377 U.S. 533 (1964).

146. See id. at 568.

147. Gray v. Sanders, 372 U.S. 368,381 (1963).

148. Id. at 384 (Harlan, J., dissenting).

149. See Powe, supra note 8; see also Thomas I. Emerson, Mr. Justice Douglas' Contribution to the Law: The First Amendment, 74 CoLUM. L. REv. 353, 354 (1974).

150. U.S. CoNST. amend. I (emphasis added). 
all the pressures of modern life toward conformity .... In this respect, Justice Douglas has given a totally new dimension to the first amendment." 151

Douglas once said that "I'd rather create a precedent than find one. Because the creation of a precedent in terms of the modern setting means the adjustment of the Constitution to the needs of the time."152 In his memoirs, Douglas acknowledged the activist label, and in terms that would have horrified Frankfurter:

My view always has been that anyone whose life, liberty or property was threatened or impaired by any branch of government-whether the President or one of his agencies, or Congress, or the courts (or any counterpart in a state regime)-had a justiciable controversy and could properly repair to a judicial tribunal for vindication of his rights. ${ }^{153}$

This is certainly not the voice of judicial restraint; it is the voice of the common law.

Yet there is much to criticize about Douglas's opimions. Even when he correctly decided difficult questions he often failed to explain how he reached these laudable results. A former law clerk and Douglas admirer, Lucas Powe, has written that Douglas did not take doctrine seriously, and failed to appreciate that others,

including those not wedded to the judicial conservatism of Harvard, did take doctrine seriously. With his acknowledged abilities he could have played the doctrinal game superbly, ${ }^{154}$ but he saw doctrine as a waste of time and he had non-legal activities that were more pressing than authoring rationalizations for those silly enough to beheve them. ${ }^{155}$

Douglas, however, had nothing but contempt for those who failed to understand the meaning of his decisions unless they had an accompanying law review article attached as explanation. "I wrote for the common man," he declared, "hoping I could help him see the main contours, and, seeing them, better understand the high vantage point we have reached with our form of government."156

One problem with complicated and unreadable opinions is that although they may appeal to the specialist, they are misunderstood by

151. Emerson, supra note 149, at 356. Emerson is not an uncritical admirer of Justice Douglas; see supra text accompanying note 106.

152. Glancy, supra note 93, at 164 (quoting CBS Reports: Mr. Justice Douglas (CBS television broadcast, Sept. 6, 1972)).

153. Court YeARS, supra note 3, at 55-56.

154. Chief Justice Rehnquist believes that some of the opinions Justice Douglas wrote earlier in his career regarding corporate finance and securities regulation show that he not only was a master of the law in those areas, but of the businesses involved, inside and out. Interview with William H. Rehnquist, Chief Justice of the United States Supreme Court, in Washington, D.C. (May 17, 1988).

155. Powe, Douglas after Fiffy Years, supra note 8, at 270.

156. William O. Douglas, An Almanac of LiberTy, at vii (1954). 
the general public. In 1977, Irving R. Kaufman, then-Chief Judge of the United States Court of Appeals for the Second Circuit, urged his fellow judges to write their opinions in a more intelligible form:

Judges often play the role of teacher or leader in shaping the public's view. As the judicial opinion is the essential document of the third branch of government, the judge should explain his action in terms that enable the reader to understand precisely what he has done and why he has done it. The democratic character of the courts' active law-making role springs from judicial participation in the marketplace of ideas, and courts, hike legislatures, must mobilize general understanding of their decisions. ${ }^{157}$

Douglas attempted this, and one can hardly deny that an intelligent layperson would find Douglas's opinions far more accessible than those of Frankfurter. ${ }^{158}$

Another problem with mvolved analytical rationalizations is that they can ignore common sense. Although stare decisis might serve as a starting point in judicial decisionmaking, Douglas remained aware of how uncertain a reed the past might be. Established law, he told Eric Severeid, was not a sure guide because the past did not always have a relevance to the present. "'I've always thought that on a constitutional decision, that stare decisis, that is, established law, was really no sure guideline because what did the guys do-tlie judges who sat there in 1875-know about, say, electronic surveillance? They didn't know anything about it. . . . Why take their wisdon?" "159 The law survived, Douglas said in 1949, because it adapted to new conditions. ${ }^{160}$ Precedents once correct might no longer be so. He called it a "healthy practice (too infrequently followed) for a court to reexamine its own doctrine."161 Again, one liears the voice of the cominon law judge. ${ }^{162}$

157. Irving R. Kaufman, Helping the Public Understand and Accept Judicial Decisions, 63 A.B.A. J. 1567 (1977). This is not to say that only short and simplistic opinions can do this. Louis Brandeis wrote to educate his brethren; his opinions, both majority and dissent, are models of judicial craftsmanship and analysis. As his law clerk Paul Freund recalled, after extensive work on a case Brandeis would often say: "The opinion is now convincing, ... but how can we make it more instructive?" Phllippa Strum, Louis D. Brandeis: Justice for the People 347 (1984).

158. See J. Louis Campbell, III, How Opinions Can Persuade: A Case Study of William O. Douglas, 29 FED. BAR NEws \& J. 231 (1982). Justice Douglas, however, seems to have eschewed adopting the role of teacher. His clerk for the 1951 Term, Marshall Small, recalled that in a tax case Justice Douglas wrote a very brief opinion. Small suggested that he expand it, and explained that Justice Harlan Fiske Stone had always attempted to elucidate the reasoning in tax cases. Justice Douglas abruptly snapped: "I don't write law review articles." Interview with Marshall Small, in San Francisco, Cal. (Aug. 26, 1988).

159. Glancy, supra note 93 , at 175 n.66 (quoting CBS Reports: Mr. Justice Douglas (CBS television broadcast, Sept. 6, 1972)).

160. See William O. Douglas, Stare Decisis, 49 Colum. L. Rev. 735, 746 (1949).

161. Id. 
Douglas has been further criticized for failing to build coalitions; he did not seem to care if he spoke for a majority or only for himself. ${ }^{163} \mathrm{His}$ colleague and fellow-activist on the Court, William J. Brennan, believes that Douglas cared passionately about the results in important cases because he did not care to be mistaken. ${ }^{164}$ But, because he could not or would not play the game of coalition building, and because he would not explain some of his opinions to influence other judges in later cases, Douglas-given his abilities and ideas-exercised far less influence than he should have. A few years before he stepped down from the bench, he conceded that " 'I haven't been much of a proselytizer on the Court .... I've had the theory that the only soul I had to save was my own." "165

These criticisms are true. Future historians will likely wonder how a man who exercised such influence on the development of American constitutional law enjoyed such a poor reputation. In the end, however, Douglas did exercise influence. According to Kenneth Karst, a self-described "second-generation disciple of Felix Frankfurter,"166 Douglas:

went his own way; he did not make concessions-and no Justice of his era did more to remake the landscape of constitutional doctrine.

Justice Douglas was the unrivaled leader of the most important constitutional development of his time: the growth of the equal protection clause. He was also a major figure in the revival of substantive due process as a protection of personal tiberties. His leadership, in other words, was precisely doctrinal leadership.

What was inissing from his opinions was the logic of the syllogism. ${ }^{167}$

162. One might point here to one of the great common law decisions of this century: Judge Cardozo's opinion in Macpherson v. Buick Motor Co., 111 N.E. 1050 (N.Y. 1916), which brought products liability law into the twentieth century by eliminating the need for privity and by establishing the liability of a manufacturer of a defective wheel to the plaintiff, the ultimate (though not immediate) purchaser. To do this, Cardozo-whom many consider the greatest coinmon law judge of this century-had to ignore precedent and write an innovative opinion to reach the right result.

163. See Kenneth L. Karst, Dedication: William O. Douglas, 1898-1980, 27 UCLA L. Rev. 511 (1980). In interviews with his clerks, I raised this issue. They all agreed that although he cared passionately, he would not try to persuade the other Justices to adopt his opinions. The following comment froin Jerome Falk is typical:

I asked him about it, I said, "Why don't you talk to [the other Justices]?" And he said several times that was not his view of what was appropriate. He would put his views out, and see what happened. He was perfectly willing to talk to people about changes, but he would never call one of them up and say, "What do I have to do to get you on board here?" Never.

Interview with Jerome Falk, in San Francisco, Cal. (Aug. 26, 1988).

164. Interview with William J. Brennan, Jr., Associate Justice of the United States Supreme Court, in Washington, D.C. (May 17, 1988).

165. Simon, supra note 4, at 250 (quoting Justice Douglas).

166. Karst, supra note 163, at 511.

167. Id. 
This is a generous and fair assessment. Douglas would have been among the first to admit that the logic of the syllogism was indeed missing. In terms of the common law, however, Holmes reminded us a century ago that the life of the law has not been logic, but experience, and all sorts of things in the real world-including the prejudices of the judges-had a great deal more to do with the law than the syllogism. ${ }^{168}$

\section{CONCLUSION}

I disagree with Professor White's assessment that William O. Douglas can or should be characterized as an anti-judge because he refused to adhere to formalistic rules. ${ }^{169}$ Nor do I agree that, as a second-generation Harvard disciple of Frankfurter claimed, Douglas was the "loose gun on the deck of the sinking ship of American liberal jurisprudence.' "170 Rather, as White correctly characterizes him, Douglas was an individualist. As such, he brought important values to the Court that other Justices did not have or appreciate. If my thesis is correct, his common law proclivities also contributed to the work of the Court in his lengtliy tenure.

Certainly, we would not want a Court of William O. Douglas clones anymore than we would want nine Felix Frankfurters. But for the Court to be responsive to changing societal needs (as was the Warren Court), it needs a nonconformist, results-oriented judge who asks the right questions-even if he or she cannot rationalize tlose results in a given manner. As Louis Jaffe wrote:

[We] should perhaps rid ourselves of the implicit assumption that there is any single model of judicial greatness. Once we recognize that the Supreme Court is a supreme policy-maker we should welcome on the Court a variety of talents and attributes-the "activist," the exponent of "judicial restraint," the liberal, the conservative, the moralist, the skeptic. Each can be great in his own way; each can contribute to the institutional product of the Court. ${ }^{71}$

For all his faults, Douglas played a critical role on the Supreme Court for thirty-five years. He asked the right questions, and more often than not, he got the right answers. In so doing, he helped his colleagues on the bench keep law sensitive to the needs of a rapidly changing society. As the Supreme Court noted in the nineteenth century, the "flexibility and capacity for growth and adaptation is the peculiar boast and

168. HOLMES, supra note 55 , at 1 .

169. See White, supra note 26 , at 18.

170. Karst, supra note 163, at 511 n.1 (quoting HARV. L. REC., Feb. 8, 1980, at 1).

171. Louis Jaffe, Was Brandeis an Activist? The Search for Intermediate Premises, 80 HARV. L. REV. 986, 1003 (1967). 
excellence of the common law." ${ }^{172}$ In this century, William O. Douglas kept that common law tradition alive.

172. Hurtado v. California, 110 U.S. 516,530 (1884). 